\title{
Patterns of alcohol use among Warsaw adolescents across 20 years_from 1988 to 2008
}

\author{
Katarzyna Okulicz-Kozaryn ${ }^{1,2}$, and Anna Borucka ${ }^{1}$ \\ ${ }^{1}$ Department of Public Health, Institute of Psychiatry and Neurology, Warsaw, Poland \\ ${ }^{2}$ State Agency for Prevention of Alcohol-Related Problems, Warsaw, Poland
}

\begin{abstract}
Aim: The study investigates patterns of alcohol drinking among 15-year-old Polish students in Warsaw over the past 20 years.

Methods: Data were collected from six consecutive surveys, beginning in $1988(N=3918)$ and conducted every four years (in 2008, $N=1229$ ).

Results: Two-step cluster analysis across all six consecutive surveys indicated a clear differentiation of the social context of adolescent alcohol drinking patterns. Adolescents are least likely to drink alcohol alone $(<5 \%)$ or heavily with peers $(<10 \%)$, more likely to drink with parents (15\%-20\%), in moderate amounts with peers $(11 \%-28 \%)$ or not at all (11\%-27\%), and most likely to be light social drinkers (30\%-46\%). Cross-gender comparisons suggest that traditional gender differences are fading away; the data show increases in moderate social drinking among females and abstinence among males.
\end{abstract}

Conclusions: Our results confirm that adolescents' patterns of alcohol use are stable over time, despite the social and political changes that have occurred in Poland since 1988, and reflect a pattern of mostly moderate drinking.

About 10 years before national surveys on adolescent alcohol use (European School Survey Project on Alcohol and other Drugs [ESPAD], and Health Behavior in SchoolAge Children [HBSC]) were conducted in Poland (Mazur \& Małkowskiej-Szkutnik, 2011; Sierosławski, 2011), a survey monitoring local trends was initiated in Warsaw (Wolniewicz-Grzelak \& Ostaszewski, 1983). It is the only survey covering a period of over 20 years, including a time of significant political, economic and social change in Poland. In 1980, the first independent trade union in the Soviet Bloc, Solidarity, was created. However, it was outlawed in 1981, when the communist government proclaimed martial law. This radical action could not stop the fall of the regime. The late 1980s were a period of agony under communist rule in Poland, as the population struggled with galloping inflation, rationing of goods, and marasmus of the society tired with the everyday life problems. In 1989, the situation changed: Solidarity was legalized again and ran candidates in the parliamentary election - the first partially free election in Poland since the Second World War. This was the beginning of a period of democratic change, which included the liberalization of governmental control over alcohol production, distribution and import, and the appearance of alcohol advertisements (Światkiewicz, 1997). In 1993, legislation limiting the number of alcohol outlets (selling beverages with more than $4.5 \%$ alcohol) was annulled, and the number of these outlets rose from 30,160 ("Profilaktyka i rozwiązywanie problemów alkoholowych,” 2006) to approximately 100,000 in 2008 ("Profilaktyka i rozwiązywanie problemów alkoholowych", 2008). These developments changed the context of drinking behaviors, including adolescent alcohol use (Okulicz-Kozaryn \& Borucka, 2008).

A Warsaw survey of adolescents found a significant increase in alcohol consumption from the mid-1980s to the mid-1990s (Okulicz-Kozaryn \& Borucka, 2006). For the past 10 years (mid-1990s to mid-2000s), the Warsaw study findings are congruent with the results of national surveys, showing similar local and national tendencies: increasing alcohol consumption up to the beginning of the 2000s, and recent stabilization (Mazur \& Małkowskiej-Szkutnik, 2011; Ostaszewski et al., 2009; Sierosławski, 2011).

The lifetime prevalence of alcohol drinking by 15 -year-old Poles has been rather stable across past decades: about $90 \%$ of teenagers have used alcohol in their lifetime (Sierosławski, 2011). Therefore, in a statistical sense, this may be interpreted as a normative behavior. However, it is not homogenous. Some youth drink alcohol only occasionally, others more often and in higher amounts.

Correspondence: Katarzyna Okulicz-Kozaryn, Department of Public Health, Institute of Psychiatry and Neurology, 9 Sobieskiego Str. 02-957 Warsaw, Poland. Telephone: + 48224582 887. Fax: + 48224582 630. E-mail: kokulicz@ipin.edu.pl

Financial support: This research was funded by the Ministry of Science and Higher Education within the framework of a statutory project in the Institute of Psychiatry and Neurology, Warsaw, Poland

Keywords: adolescents, alcohol drinking patterns, gender differences, time trends 
As described below, several drinking patterns exist among adolescents, distinguished by the level of alcohol consumed and the size and gender composition of drinking groups. Although the differences between various styles of alcohol use are not clear-cut, classifying specific types or groups of adolescents is useful for the description and understanding of alcohol use as a social phenomenon.

Probably the most studied type is "social drinking," usually described as drinking with others to experience positive emotional states and pleasant situations (Mohr et al., 2001). Some social drinkers drink in small quantities, while others drink much more (Senchak, Leonard, \& Greene, 1998). Moderate social drinkers are sometimes called "competent" drinkers, since they do not enter into risky situations related to drunkenness (Bogren, 2006), while heavy social drinkers tend to have heavy-drinking episodes but do not drink alone (Christiansen, Vik, \& Jarchow, 2002). Demant and Torronen (2011) distinguish "heroic" and "playful” styles among heavy, intoxication-oriented drinkers; the first is characterized by extreme, individual experiences, while the second is more audience oriented and controlled.

Some researchers use the term "social drinking" when referring to those who have never drunk alone (Tucker, Ellickson, Collins, \& Klein, 2006). In fact, drinking alone, or "solitary drinking," used to be defined in the literature as episodic behavior which does not exclude drinking in company and may even be assumed to include customary social drinking (Bourgault \& Demers, 1997).

Another pattern of teenage alcohol use that is interesting from a psychosocial perspective concerns drinking with, or getting alcohol from, parents, or drinking in the parental home. Like solitary drinking, drinking with parents is not clearly separated from other drinking styles. Adolescents who occasionally drink with parents tend to drink alcohol with peers as well. Statistically, this pattern of alcohol use is associated with not getting drunk and not using alcohol in public places (Bellis et al., 2007; Forsyth \& Barnard, 2000). Our previous research indicated that alcohol use with parents was most common among teenage moderate drinkers (Okulicz-Kozaryn \& Borucka, 2008).

In the present study, we investigated past and current patterns of alcohol drinking among Warsaw 15-year-olds. As we know from previous analysis across the past 20 years, significant changes have occurred in the prevalence of alcohol consumption. Now, we ask whether the social context of drinking has changed as well.

\section{Method}

\section{Procedure}

The study is based on data from a drug use monitoring survey conducted every four years among students from one part of Warsaw (in the 1980s the area was a single district, Mokotow; it is now divided into three separate administrative units). Data from six consecutive surveys (1988, 1992, 1996, 2000, 2004 and 2008) were analyzed (due to technical problems, it was not possible to include data from 1984). At all time points, data were collected at the beginning of the school year (Fall). Between 1988 and 2000 , the participants of the survey were in the first grade of high school and the majority of them were 15 years old. Since 2004, due to structural changes in the educational system, the same age group has been in the final (third) grade of middle school.

In 1988, all first-grade classes from all high schools in this district participated in the study. Since 1992, approximately $50 \%$ of classes have been randomly selected. At all time points, classroom surveys were conducted by trained research staff who had no connection with the schools. The anonymity of individual students, classes and schools was guaranteed.

\section{Participants}

The number of participants ranged from 3,918 in 1988 to 1,229 in 2008 (there were 2,000 students in 1992; 2,484 in 1996; 2,471 in 2000; and 1,461 in 2004). Between 1988 and 2000 , there were more girls $(51 \%-53 \%)$ than boys in the sample. This proportion changed in 2004, when boys were in the majority (52\%). Every year, the percentage of students absent from school on the day of the survey was similar and did not exceed 10\% (Ostaszewski et al., 2009). The social status of students participating in the study has never been directly assessed in the survey. Nevertheless, random selection of school classes from this area which is representative for the whole Warsaw (Cichomski, 2004) suggests that students' social characteristics are similar to the general population of the Polish capital city.

\section{Measurement}

Alcohol use is measured by the description of the last drinking occasion. This is based on the assumption that in big samples, the last drinking occasion is representative of usual consumption, and this measure may be more precise than recalling longer time periods since there is less risk of memory error and bias (Święcicki, 1963; WolniewiczGrzelak, 1985).

Respondents were asked "when" and "in what quantity" they had last used three kinds of alcoholic beveragesbeer, wine, and vodka-for a total of six questions (Wolniewicz-Grzelak, 1995). Nine response options for time of last consumption were provided, ranging from 0 : "I've never drunk" to 8: "from 1 to 4 days ago"). For the quantity questions, a 7-point scale was used (from 0: "I've never drunk" to 6: "more than 4 bottles" [for beer drinking], "a bottle or more" [for wine drinking], and " $1 / 4$ litre or more" [for vodka drinking]). An overall scale of alcohol use was computed by totaling scores from the frequency and quantity questions. It ranged from 0 (abstinence) to 26 (drinking 1-4 days ago; beer, wine and vodka in maximum quantities).

To describe with whom they had last been drinking, the respondents were to choose one of the following options: "with parents," "with other adults," "only with teenagers," "alone." Because of the relatively low rate of adolescents 
choosing "other adults," and the ambiguity of this answer ("other adults" tells us only that these were not the respondent's parents; they could be other adult relatives, friends of the parents, older friends of the respondent, or strangers), the group of adolescents who chose this answer was excluded from further analysis.

\section{Data analysis}

The measures of alcohol use and drinking companions were combined to reveal natural groups of adolescent differentiated by the predominant drinking preference for each person. Since one of these variables (assumed to be independent) is categorical, the two-step cluster analysis method was used ${ }^{1}$. In this procedure cases represent objects to be clustered. The first case from the data set is taken as a reference, and all other cases are successively compared to it. This approach, however, does make the statistic sensitive to case order. To minimize this effect, cases were put into different random orders (uniform and student's $t$ distributions were used). To verify the stability of this solution, 10 runs were conducted with cases sorted into different random orders. As well, the BIC criterion for auto-clustering was applied. The results were displayed separately for each year of the survey.

\section{Results}

Clusters were automatically identified by the statistical software in each year of the study, as follows:

- 1988: (1) abstainers (never drank alcohol); (2) social drinkers (last drank with peers); and (3) others (last drank with parents or alone).

- 1992: (1) abstainers; (2) family drinkers (last drank with parents); (3) solitary drinkers (last drank alone); (4) social light drinkers (last drank with peers, in limited amounts); (5) social moderate drinkers (last drank with peers, but in larger quantities than light drinkers); (6) social heavy drinkers (last drank with peers, in high quantities).

- 1996: the same clusters as in 1992.

- 2000: (1) social drinkers; (2) others (abstainers, family and solitary)

- 2004: (1) abstainers; (2) family drinkers; (3) solitary drinkers; (4) social light/moderate drinkers (last drank with peers, in lower quantities than respondents in cluster 5); (5) social moderate/heavy drinkers (last drank with peers, more than those in cluster 4).

- 2008: the same clusters as in 1992 and 1996.

Table 1 shows the prevalence of each drinking pattern revealed in a given year and the average amount of alcohol consumed by adolescents classified into different clusters.

To analyze changes over time in various groups of adolescents, for the next set of two-step cluster analysis, the number of clusters was fixed at six, as this was the most prevalent number of clusters across the years. As Figure 1 shows, the most stable feature over time is the prevalence of solitary drinking ( $4 \%$ of the population) and social heavy drinking (6\%-7\%). The percentage of adolescents drinking with parents increased slightly (from $15 \%-17 \%$ in the ' 90 s, to $19 \%-20 \%$ in the 2000 s). The most significant changes are visible in the most prevalent drinking patterns. Light drinking with peers, which had been increasing up to the end of the ' 90 s (from 30\% in 1992 to $43 \%$ in 1996), recently diminished to $29 \%$. The opposite trends may be observed for abstinence, which had been decreasing-from $27 \%$ in 1988 to $11 \%$ in 1996 - but has been increasing since then, to $19 \%$ in 2008 . Social moderate drinking was the most popular category at the beginning of our survey ( $30 \%$ in 1992); later, it diminished to $11 \%$, then in 2008 it returned to 1988 levels (21-22\%).

Mean alcohol use in the cluster of adolescents who drink with parents has been low and stable across the years (from 1.57 to 1.73, Figure 2). Also stable, but slightly higher, have been the indicators of alcohol consumption among social light drinkers (from 1.52 to 1.94 ) and adolescents drinking alone (2.42-2.70). The average consumption of social moderate drinkers increased between 1988 (3.94) and 2004 (7.26), but in 2008 was lower again (5.63) although not as low as the 1988 level. The same trend may be observed among social heavy drinkers (average alcohol use $=9.16$ in 1992, 12.72 in 2004, and 11.21 in 2008).

Cross-gender comparisons (Table 2) indicate that drinking with parents has been more popular among teenage females (20\% and higher) than males (13\%-17\%). Other drinking patterns have followed different trends over time: (1) abstinence was more prevalent among girls in the ' 80 s and '90s, but in 2004 become more popular among boys; (2) gender differences relating to social moderate, social heavy, and solitary drinking (traditionally more prevalent among boys) have been diminishing since the beginning of the 2000s; (3) since the mid-1990s, social light drinking has been more prevalent among girls than boys.

\section{Discussion}

Despite the gaps between surveys (four years), the extended period of time covered (twenty years), and significant social and political changes (transition from communism to a market economy system), our study revealed several patterns of alcohol use by 15-year-old Poles that have been stable over time. This finding is statistically confirmed and is in accordance with findings from studies in other countries (Bogren, 2006; Bourgault \& Demers, 1997; Christiansen et al., 2002; Mohr et al., 2001; Senchak et al., 1998). The main differences are between adolescents who drink alcohol with peers (social drinkers), and all others (including abstainers), with a general increase in social drinkers until the 2008 survey. However, social drinkers are not a homogenous group; some of them drink heavily, others in much lower amounts.

\footnotetext{
1 Statistical package SPSS PC version 15.0
} 
Table 1.

Cluster characteristics across years

\begin{tabular}{|c|c|c|c|c|c|c|}
\hline \multirow[b]{3}{*}{ Year } & \multicolumn{6}{|c|}{ Clusters } \\
\hline & \multirow[b]{2}{*}{ Abstainers } & \multirow{2}{*}{$\begin{array}{l}\text { Family } \\
\text { drinkers }\end{array}$} & \multirow[b]{2}{*}{ Solitary drinkers } & \multicolumn{3}{|c|}{ Social drinkers } \\
\hline & & & & Light & Moderate & Heavy \\
\hline 1988 & $\begin{array}{l}N=946(27 \%) \\
\text { avg.alc } .=0.01\end{array}$ & \multicolumn{2}{|c|}{$N=858(25 \%)$ avg.alc. $=1.83$} & \multicolumn{3}{|c|}{$N=1688$ (48\%) avg.alc. $=3.51$} \\
\hline 1992 & $\begin{array}{l}N=262(14 \%) \\
\text { avg.alc. }=0.01\end{array}$ & $\begin{array}{l}N=313(17 \%) \\
\text { avg.alc. }=1.73\end{array}$ & $\begin{array}{c}N=78(4 \%) \\
\text { avg.alc. }=2,56\end{array}$ & $\begin{array}{l}N=539(30 \%) \\
\text { avg.alc. }=1.52\end{array}$ & $\begin{array}{l}N=504(28 \%) \\
\text { avg.alc. }=3.98\end{array}$ & $\begin{array}{c}N=124(7 \%) \\
\text { avg.alc. }=9.16\end{array}$ \\
\hline 1996 & $\begin{array}{l}N=250(11 \%) \\
\text { avg.alc. }=0.01\end{array}$ & $\begin{array}{l}N=347(15 \%) \\
\text { avg.alc. }=1.65\end{array}$ & $\begin{array}{c}N=90(4 \%) \\
\text { avg.alc. }=2.60\end{array}$ & $\begin{array}{l}N=978(43 \%) \\
\text { avg.alc. }=1.90\end{array}$ & $\begin{array}{l}N=489(21 \%) \\
\text { avg.alc. }=5.44\end{array}$ & $\begin{array}{c}N=130(6 \%) \\
\text { avg.alc. }=11.44\end{array}$ \\
\hline 2000 & \multicolumn{3}{|c|}{$N=711(32 \%)$ avg.alc. $=1.20$} & \multicolumn{3}{|c|}{$N=1511$ (68\%) avg.alc. $=3.81$} \\
\hline 2004 & $\begin{array}{l}N=177(14 \%) \\
\text { avg.alc. }=0.03\end{array}$ & $\begin{array}{l}N=248(20 \%) \\
\text { avg.alc. }=1.63\end{array}$ & $\begin{array}{c}N=57(4 \%) \\
\text { avg.alc. }=2.70\end{array}$ & $N=580(46 \%)$ as & $=2.58$ & ) avg.alc. $=8.83$ \\
\hline 2008 & $\begin{array}{l}N=202(19 \%) \\
\text { avg.alc. }=0.04\end{array}$ & $\begin{array}{l}N=197(19 \%) \\
\text { avg.alc. }=1.57\end{array}$ & $\begin{array}{c}N=43(4 \%) \\
\text { avg.alc. }=2.42\end{array}$ & $\begin{array}{l}N=305(29 \%) \\
\text { avg.alc. }=1.94\end{array}$ & $\begin{array}{l}N=221(21 \%) \\
\text { avg.alc. }=5.63\end{array}$ & $\begin{array}{c}N=75(7 \%) \\
\text { avg.alc. }=11.21\end{array}$ \\
\hline
\end{tabular}

\section{Figure 1}

The prevalence of alcohol use patterns among Warsaw adolescents, 1988-2008

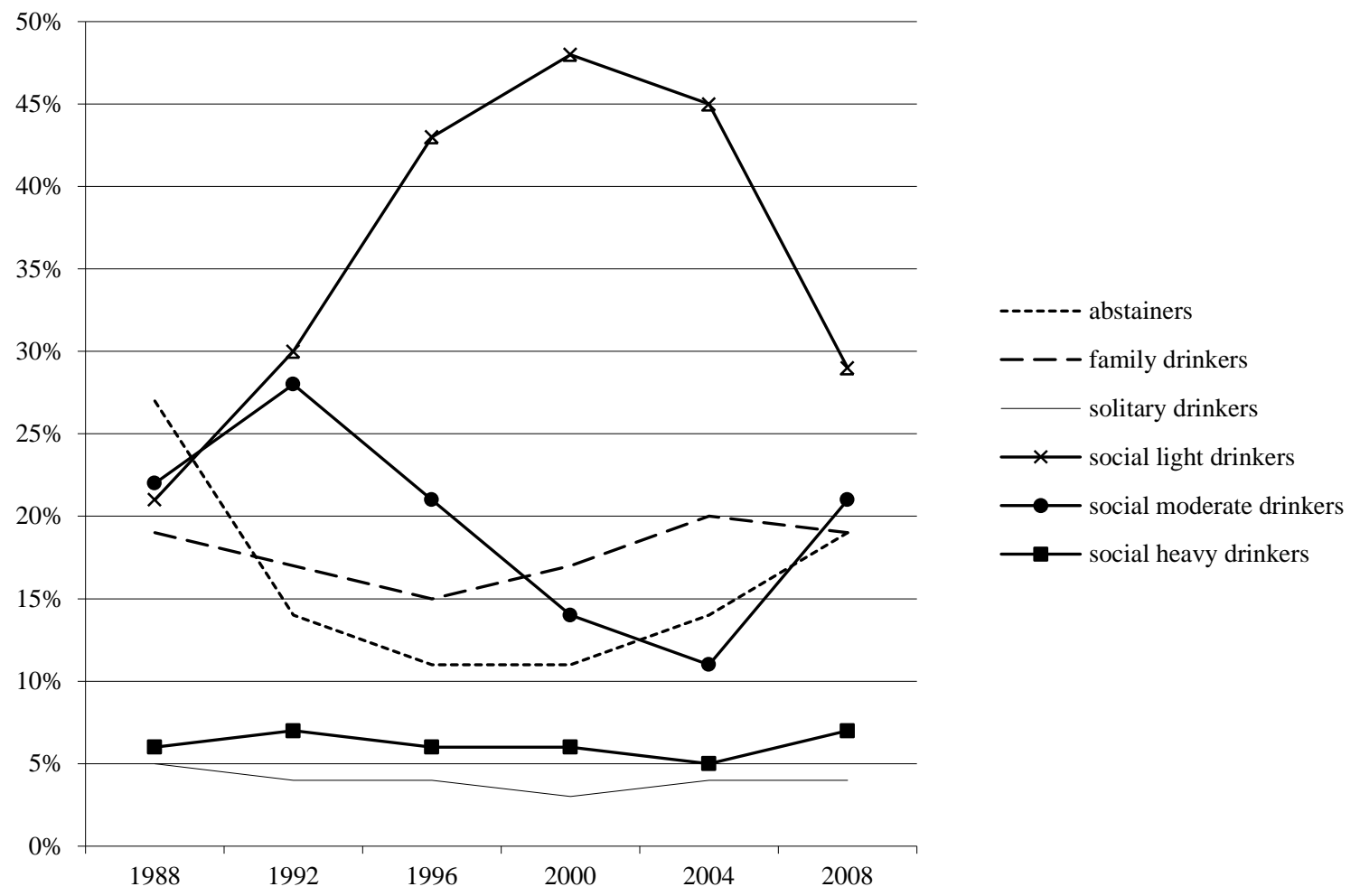




\section{Figure 2}

Average number of drinks consumed by Warsaw adolescents, grouped in five clusters of alcohol users, 1988-2008

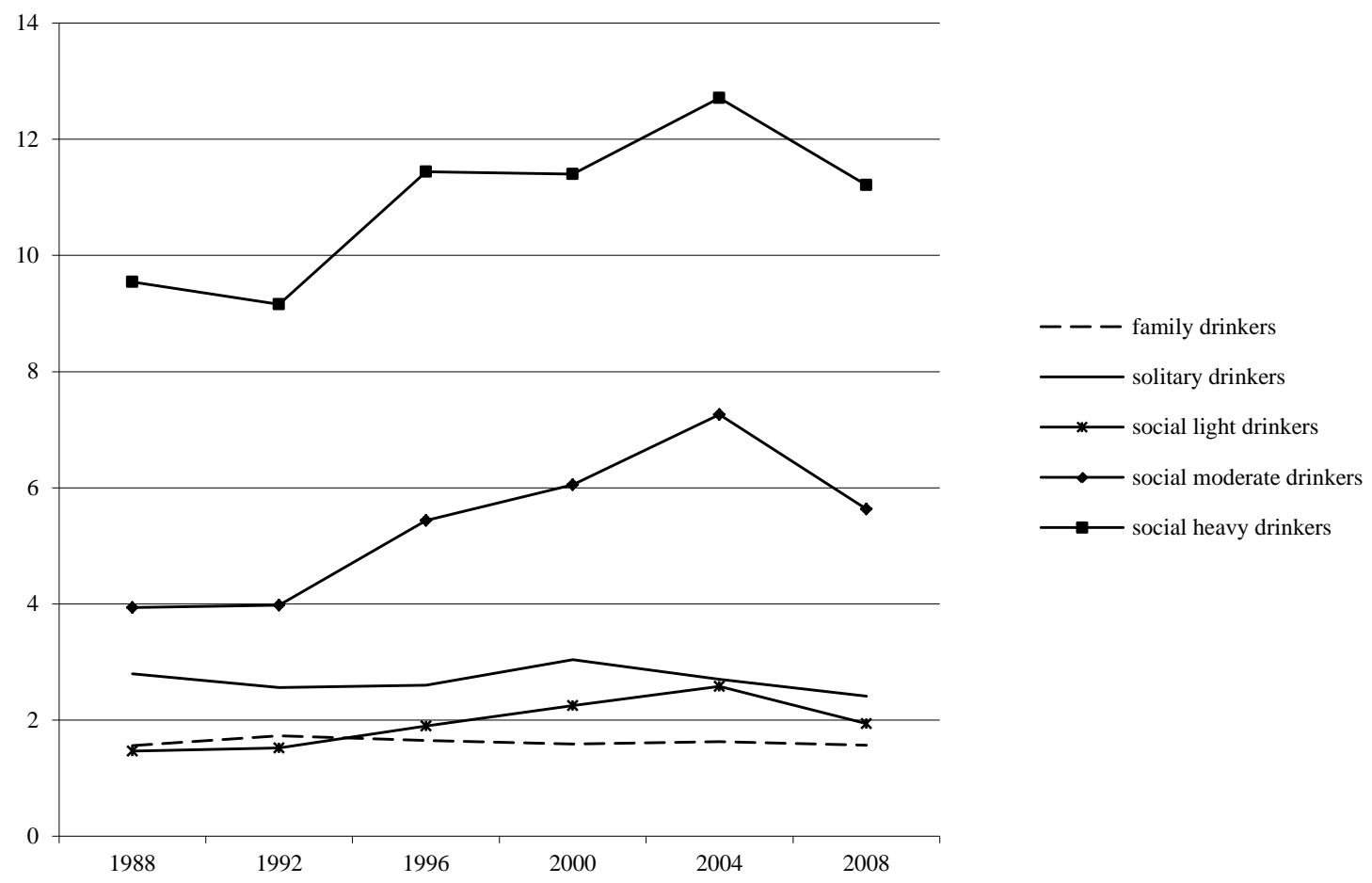

Table 2.

Cross-gender comparisons of the prevalence of alcohol use patterns among Warsaw adolescents, 1988-2008

\begin{tabular}{|c|c|c|c|c|c|c|c|c|}
\hline \multirow{3}{*}{$\begin{array}{l}\text { Year } \\
(N)\end{array}$} & \multirow[b]{3}{*}{ Gender } & \multicolumn{6}{|c|}{ Clusters } & \multirow[b]{3}{*}{$X^{2}$} \\
\hline & & \multirow[b]{2}{*}{ Abstainers } & \multirow{2}{*}{$\begin{array}{c}\text { Family } \\
\text { drinkers }\end{array}$} & \multirow{2}{*}{$\begin{array}{l}\text { Solitary } \\
\text { drinkers }\end{array}$} & \multicolumn{3}{|c|}{ Social drinkers } & \\
\hline & & & & & Light & Moderate & Heavy & \\
\hline \multirow{2}{*}{$\begin{array}{c}1988 \\
(3492)\end{array}$} & female & $32 \%$ & $23 \%$ & $3 \%$ & $22 \%$ & $18 \%$ & $2 \%$ & \multirow[t]{2}{*}{200.854 *** } \\
\hline & male & $21 \%$ & $16 \%$ & $7 \%$ & $20 \%$ & $26 \%$ & $10 \%$ & \\
\hline \multirow{2}{*}{$\begin{array}{c}1992 \\
(1808)\end{array}$} & female & $18 \%$ & $20 \%$ & $2 \%$ & $31 \%$ & $25 \%$ & $4 \%$ & \multirow[t]{2}{*}{$72.510^{* * *}$} \\
\hline & male & $11 \%$ & $14 \%$ & $6 \%$ & $28 \%$ & $31 \%$ & $10 \%$ & \\
\hline \multirow{2}{*}{$\begin{array}{c}1996 \\
(2262)\end{array}$} & female & $13 \%$ & $17 \%$ & $3 \%$ & $47 \%$ & $18 \%$ & $3 \%$ & \multirow[t]{2}{*}{$77.262 * * *$} \\
\hline & male & $9 \%$ & $13 \%$ & $5 \%$ & $39 \%$ & $26 \%$ & $8 \%$ & \\
\hline \multirow{2}{*}{$\begin{array}{c}2000 \\
(2208)\end{array}$} & female & $11 \%$ & $20 \%$ & $2 \%$ & $52 \%$ & $11 \%$ & $4 \%$ & \multirow[t]{2}{*}{$50.501 * * *$} \\
\hline & male & $12 \%$ & $15 \%$ & $5 \%$ & $44 \%$ & $17 \%$ & $8 \%$ & \\
\hline \multirow{2}{*}{$\begin{array}{c}2004 \\
(1255)\end{array}$} & female & $10 \%$ & $23 \%$ & $4 \%$ & $47 \%$ & $12 \%$ & $4 \%$ & \multirow[t]{2}{*}{$24.394^{* * *}$} \\
\hline & male & $18 \%$ & $17 \%$ & $5 \%$ & $44 \%$ & $11 \%$ & $5 \%$ & \\
\hline \multirow{2}{*}{$\begin{array}{c}2008 \\
(1036)\end{array}$} & female & $16 \%$ & $23 \%$ & $3 \%$ & $33 \%$ & $20 \%$ & $5 \%$ & \multirow[t]{2}{*}{$30.808 * * *$} \\
\hline & male & $23 \%$ & $15 \%$ & $5 \%$ & $25 \%$ & $23 \%$ & $9 \%$ & \\
\hline
\end{tabular}

$* * * \mathrm{p}<0.000$ 
Comparing the prevalence of various drinking patterns across 20 years indicates that the smallest groups of adolescents were those who drank alcohol alone $(<5 \%)$ or heavily with peers $(<10 \% \%)$. Larger percentages of adolescents reported drinking with parents (15\%-20\%), drinking in moderate amounts with peers (11\%-28\%), or remaining abstinent (11\%-27\%), while the largest group has consistently been that of social light drinkers (30\%$46 \%)$.

Time trends comparison indicates a significant decrease in the rate of abstainers and increase in the rate of social drinkers (especially light drinkers) after 1988. Changes in alcohol consumption after the fall of communism in Poland in 1989 are mainly due to the introduction of a free market economy, which meant increased availability of alcohol, aggressive marketing, and better quality of alcoholic beverages, especially beer. Changing social attitudes also played a role, as the influence of the Catholic Church weakened and social norms regarding adequate and nonadequate behaviors were liberalized (Okulicz-Kozaryn \& Borucka, 2008).

Recently, however, the percentages of adolescents not drinking at all, drinking with parents, and drinking socially in moderate amounts tend to approximate each other (at the level of about 20\%). The percentage of adolescents classified as light social drinkers approaches this level as well. This trend may indicate increasing social tolerance for various alcohol drinking patterns (including abstinence) among teenagers. But it remains unclear what social (macro, parental, and/or peer) factors are responsible for this phenomenon. Maybe the magic of market freedom and the ease of obtaining goods do not affect teenagers of the $21^{\text {st }}$ century to the extent it affected previous generations. The great majority of our study respondents in the 2004 survey were born in 1989, so they do not remember times of political and economic constraint. Another hypothetical explanation is that alcohol use tended to lose importance as a determinant of status within the peer group (Bogren, 2006; Demant \& Jarvinen, 2006; 2011; Jarvinen \& Gundelach, 2007; Tucker et al., 2006). This suggests a need for exploration of other behaviors which may have taken over the social function of alcohol drinking, such as cannabis use or activities in social media.

The inversion, in 2004, of the growth trend of the most prevalent drinking style-light social drinking-may be associated with structural changes in the Polish educational system. In 2004, 15-year-olds, who were previously in the lowest grade of high school, became the oldest students in middle school, which may have worked for them as a protective factor against alcohol use (Kuntsche, Gmel, Wicki, Rehm, Grichting, 2006). However, a reversal of negative tendencies for other drinking styles and quantity of alcohol consumed appeared later, in 2008, suggesting a weak association between alcohol consumption and students' age relative to others within their school.

Only two drinking patterns had low prevalence: drinking alone and social heavy drinking. Both of these are described in the literature as "bad" or "sad" in young people's narratives, because they are contrary to collective and joyful mainstream drinking (Demant \& Jarvinen, 2011). They are also related to the highest actual and future risk (Christiansen et al., 2002; Tucker et al., 2006). However, the rather low amounts of alcohol consumed by adolescents drinking alone suggest they may be at a higher risk of stronger beliefs concerning the ability of alcohol to enhance positive or attenuate negative affect (Mohr et al., 2001), but that their risk of social or health consequences is not significantly higher than for other drinkers (Bourgault \& Demers, 1997; Gonzales, Collins, \& Bradizza, 2009).

Comparison of the prevalence of various drinking patterns among males and females suggests that traditional gender differences are fading away. This is especially visible for social drinking, regardless of the level of consumption. As Demant and Torronen (2011) emphasize, this process, observed in several countries, is related to an increase in women's activity (including alcohol drinking) in public places, a decline in social perceptions of female drinking as immoral, and adoption of a more playful drinking style (as opposed to heroic drinking) by boys. Moreover, in our study, we observed increasing rates of abstinence among boys beginning in the mid-2000s. This may be related to the fact that boys tend to spend more time in privateplaying computer games or using the internet—which prevents them from spending time with peers. In contrast, girls spend more time outside of the home (Ostaszewski, et al. 2005).

Only drinking with parents remains more prevalent among girls than boys, as it was twenty years ago. Probably, this reflects the stability of parental attitudes toward teenage drinking, and suggests that parents are more willing to introduce daughters than sons to alcohol in home. Unfortunately, the phenomenon of introducing a child to alcohol in the home (Abar, Abar, \& Turrisi, 2009; Bellis et al., 2009; Smyth, Marker, Donnelly-Swift, Barry, \& Allwright, 2010; Warner \& White, 2003) is not widely explored yet, and more research explaining gender differences is needed.

Some limitations of this study have to be taken into account. First of all, the aspiration to maintain the comparability of survey results across the years led to very minor modifications to the study procedure and questionnaire. Generally, methodological solutions chosen over 20 years ago are still currently acceptable. However, asking about the last drinking occasion is not popular in present studies (e.g., in ESPAD and HBSC, respondents are asked about alcohol use in a given past period), though it is sometimes still used as a measure of a typical drinking occasion-for example, in Forsyth and Barnard's 2000 study focusing on the places in which school-aged Scottish adolescents report using alcohol. Both measures of alcohol consumption-asking about average alcohol consumption in a given period of time and asking about the last drinking occasion-have different estimation errors. In the first method, the bias is related to respondents' inability to assess their average consumption, especially over longer time periods and when drinking is irregular and doses highly differentiated. The main problem with the second 
measure concerns the difficulty of drawing conclusions about usual consumption patterns based only on the last drinking occasion. As mentioned earlier, our study is based on the assumption that this kind of generalization is justified in big samples (Święcicki, 1963; WolniewiczGrzelak, 1985). Comparisons of our study results with the alcohol use trends found in national surveys (Mazur \& Małkowskiej-Szkutnik, 2011; Sierosławski, 2011) generally confirm the accuracy of assessments based on descriptions of the last drinking occasion. Empirical verification of this assumption would be useful, however, especially for the assessment of alcohol doses, since with knowledge of only one case of alcohol use, it is not possible to derive conclusions about the average quantities of alcohol consumed by adolescents. We are aware that in our study, the assessments of the quantities of alcohol used by students are inaccurate and are useful only for comparisons in time.

The possibility of generalizing this study's results is limited by its local context-it covers only a part of Warsaw, Poland. Therefore, there are dangers in drawing conclusions regarding the general population of Polish adolescents. However, as the results concerning average level of alcohol consumed across years are generally consistent with national studies (Mazur \& MałkowskiejSzkutnik, 2011; Sierosławski, 2011), it seems highly plausible that similar patterns of alcohol use would be found amongst adolescents in other settings.

\section{Acknowledgements}

We thank Professor Petra Meier and Professor Peter M. Miller for their valuable contributions within the ISAJE Mentoring Program.

This paper was prepared within the framework of statutory project 501-102-08028 in the Institute of Psychiatry and Neurology, Warsaw, Poland.

\section{References}

Abar, C., Abar, B., \& Turrisi, R. (2009). The impact of parental modeling and permissibility on alcohol use and experienced negative drinking consequences in college. Addictive Behaviors, 34, 542-547.

Bellis, M. A., Hughes, K., Morleo, M., Tocque, K., Hughes, S., Allen, T., Harrison, D., \& Fe-Rodriguez, E. (2007). Predictors of risky alcohol consumption in schoolchildren and their implications for preventing alcohol-related harm. Substance Abuse Treatment, Prevention, and Policy, 2, 15. doi:10.1186/1747597X-2-15

Bellis, M. A., Phillips-Howard, P. A., Hughes, K., Hughes, S., Cook, P. A., Morleo, M., .. . \& Jones, L. (2009). Teenage drinking, alcohol availability and pricing: A cross-sectional study of risk and protective factors for alcohol-related harms in school children. BMC Public Health, 9, 380. doi:10.1186/1471-2458-9-380
Bogren, A. (2006). The competent drinker, the authentic person and strong person: Lines of reasoning in Swedish young people's discussions about alcohol. Journal of Youth Studies, 9, 515-538.

Bourgault, C., \& Demers, D. (1997). Solitary drinking: A risk factor for alcohol-related problems? Addiction, 92, 303-312.

Christiansen, M., Vik, P., W., \& Jarchow, A. (2002). College student heavy drinking in social context versus alone. Addictive Behaviors 27, 393-404.

Cichomski, B. (2004). Zróżnicowanie społeczne mieszkańców Warszawy w perspektywie porównawczej (Social diversification of Warsaw inhabitants from comparative perspective). In J. Grzelak, \& T. Zarycki (Eds.), Połeczna mapa Warszawy. Interdyscyplinarne stadium metropolii warszawskiej (Social map of Warsaw. Interdisciplinary study of Warsaw metropolis) (pp. 11-42). Warszwa: Scholar.

Demant, J., \& Jarvinen, M. (2006). Constructing maturity through alcohol experience-Focus group interviews with teenagers. Addiction Research and Theory, 14, 589-602.

Demant, J., \& Jarvinen, M. (2011). Social capital as a norm and resources: Focus groups discussing alcohol. Addiction Research and Theory, 19, 91-101.

Demant, J., \& Torronen, J. (2011). Changing drinking styles in Denmark and Finland: Fragmentation of male and female drinking among young adults. Substance Use \& Misuse, 46, 1244-1255.

Forsyth, A., \& Barnard, M. (2000). Preferred drinking locations of Scottish adolescents. Health \& Place, 6, 105-115.

Gonzales, V. M., Collins, R. L., \& Bradizza, C. M. (2009). Solitary and social heavy drinking, suicidal ideation and drinking motives in underage college drinkers. Addictive Behaviors 34, 993-999.

Jarvinen, M., \& Gundelach, P. (2007). Teenage drinking, symbolic capital and distinction. Journal of Youth Studies, 10, 55-71.

Kuntsche, E., Gmel, G., Wicki, M., Rehm, J., \& Grichting, E. (2006). Disentangling gender and age effects on risky single occasion drinking during adolescence. European Journal of Public Health, 16, 670-675.

Mazur, J., \& Małkowskiej-Szkutnik, A. (2011). Wyniki badań HBSC 2010. Raport techniczny, (The results of HBSC 2010. The technical report). Warszawa: Instytut Matki i Dziecka.

Mohr, C. D., Armeli, S., Tennem, H., Carney, M. A., Affeck, G., \& Hromi, A. (2001). Daily interpersonal experiences, context and alcohol consumption: Crying in your beer and toasting good times. Journal of Personality and Social Psychology, 80, 489-500.

Okulicz-Kozaryn, K., Borucka A. (2006). Zmiany w piciu alkoholu przez warszawskich nastolatków w latach 1984-2004. (Changes in alcohol consumption among Warsaw adolescents between 1984-2004). Alkoholizm i Narkomania (Alcohol and Drug Abuse), 19, 243-258.

Okulicz-Kozaryn, K., \& Borucka, A. (2008). Warsaw adolescent alcohol use in period of social change in Poland: Cluster analyses of five consecutive surveys, 1988 to 2004. Addictive Behaviors, 33, 439-450. 
Ostaszewski, K., Bobrowski, K., Borucka, A., Kocoń, K., Cybulska M., Okulicz-Kozaryn, K., \& Pisarska, A. (2009). Raport techniczny $\mathrm{z}$ realizacji projektu badawczego pn. Monitorowanie zachowań ryzykownych młodzieży. Badania mokotowskie. (Technical report from the survey titled Monitoring adolescents' risky behaviors. Mokotow Study). Warszawa: Instytut Psychiatrii i Neurologii.

Ostaszewski, K., Bobrowski, K., Borucka, A., Kocoń, K., Okulicz-Kozaryn, K., \& Pisarska, A. (2005). Raport techniczny $\mathrm{z}$ realizacji projektu badawczego pn. Monitorowanie trendów używania substancji psychoaktywnych oraz wskaźników innych wybranych aspektów zdrowia psychicznego młodzieży szkolnej (Technical report from the survey titled Monitoring of trends in psychoactive substance use and selected indicators of mental health among school students). Warszawa: Instytut Psychiatrii i Neurologii.

Profilaktyka $i$ rozwiazywanie problemów alkoholowych $w$ samorzadach lokalnych. Zestawienia statystyczne. (Prevention and solving of alcohol related problems in local governments. Statistical specifications). (2006). Warszawa: Wydawnictwo Edukacyjne PARPA

Profilaktyka $i$ rozwiqzywanie problemów alkoholowych $w$ Polsce $w$ samorzadach gminnych 2008 roku (Prevention and solving of alcohol problems in local government in Poland in 2008, the municipal). Retrieved from http://www.parpa.pl/download/ Zestawienia\%20statystyczne\%202008.pdf

Senchak, M., Leonard, K. E., \& Greene, B. W. (1998). Alcohol use among college students as a function of their typical social drinking context. Psychology of Addictive Behaviors, 12, 62-70.

Sierosławski, J. (2011). Używanie alkoholu $i$ narkotyków przez mtodzież szkolnq. Raport $z$ ogólnopolskich badań ankietowych zrealizowanych $w 2011$ r. (Alcohol and drug use among school children: Report from the 2011 nationwide survey). Warszawa: IPiN. Retrieved from http://www.parpa.pl/images/file/ Raport\%20ESPAD.pdf

Smyth, B. P., Marker, C. D., Donnelly-Swift, E., Barry, J. M., \& Allwright, S. (2010). A telephone survey of parental attitudes and behaviors regarding teenage drinking. BMC Public Health, 10, 29. Retrieved from http://www.biomedcentral.com/1471-2458/10/297

Świątkiewicz, G. (1997). Ekonomiczno-społeczne uwarunkowania problemów związanych z alkoholem (Socio-economic determinants of alcohol-related problems). Alkoholizm i Narkomania (Alcohol and Drug Abuse), 2, 147-161.

Święcicki, A. (1963). Struktura spożycia napojów alkoholowych $w$ Polsce na podstawie badań ankietowych (Structure of alcohol use in Poland on the basis of poll survey). Warszawa: SPK.

Tucker, J., S., Ellickson, P., L., Collins, R., L., \& Klein, D., J. (2006). Does solitary substance use increase adolescents' risk for poor psychosocial and behavioral outcomes? A 9-year longitudinal study comparing solitary and social users. Psychology of Addictive Behavior, 20, 363-372.
Warner, L. A., \& White, H. R. (2003). Longitudinal effects of age at onset and first drinking situations on problem drinking. Substance Use \& Misuse, 38, 1983-2016.

Wolniewicz-Grzelak, B. (1985). Badania ankietowe nad spożywaniem alkoholu przez uczniów szkół podstawowych Mokotowa w 1984 roku i niektóre problemy metodologiczne (Questionnaire surveys on alcohol use among primary school students from Mokotow district in 1984 and some methodological problems). Biuletyn Instytutu Psychoneurologicznego, 4, 65-85.

Wolniewicz-Grzelak, B. (1995). Badanie picia napojów alkoholowych przez młodzież arkuszem "Piwo-WinoWódka." (Assessing youth drinking patterns by using a questionnaire "Beer-Wine-Vodka”). Alkoholizm $i$ Narkomania, 2, 117-127.

Wolniewicz- Grzelak, B., \& Ostaszewski, K.(1983). Badanie środowisk szkolnych w zakresie zagrożenia uzależnieniem od środków odurzających. (Assessing school environment in the domain of risk of psychoactive substance addiction). Biuletyn Instytutu Psychoneurologicznego, 4, 68-82. 